\title{
A new conceptualization of union commitment: development and test of an integrated theory
}

\author{
MAGNUS SVERKE \\ Swedish Institute for Work Life Research, Sweden \\ SAROSH KURUVILLA \\ School of Industrial Relations, Cornell University, USA
}

\section{Summary}

An introductory conceptual and empirical review stresses the need for a stable theoretical basis for union commitment research. The purpose of this paper is to develop a new conceptualization of union commitment based on the integration of two theories (the theory of reasoned action and the rationalistic approach to commitment). The integrated theory suggests that union commitment is composed of two dimensions, one based on instrumentality and one based on ideology, which are causally related to pro-union behavioral intentions and, in turn, to union participation. Propositions derived from the integrated theory are tested using data on 1486 blue-collar workers in Sweden. Results of linear structural equation modelling with latent variables and of multiple regression analyses provide strong support for the construct validity of the commitment dimensions and the overall applicability of the integrated theory. The central findings, their conceptual implications for the understanding of union commitment, and their practical implications for unions are discussed.

\section{Introduction}

As voluntary organizations, unions depend upon their members acting voluntarily in ways which facilitate the achievement of union goals. As Gordon, Philbot, Burt, Thompson and Spiller (1980, p. 480) suggest: 'Since the ability of union locals to attain their goals is generally based on the members' loyalty, belief in the objectives of organized labor, and willingness to perform services voluntarily, commitment is part of the very fabric of unions'. Apart from its practical value to unions, research on union commitment contributes to the understanding of the psychological processes involved in social and collective action generally.

Union commitment research has burgeoned since Gordon and his colleagues (Gordon et al., 1980) first developed their union commitment scale. Since then, a survey of the literature shows a growing number of studies that have examined different aspects of union commitment, such as its 
measurement, its structure, and its antecedents and consequences in both national and comparative contexts. The number of researchers active in the area has also risen substantially, judging from the increasing number of conferences devoted to this theme (e.g. the international conference on union commitment in Amsterdam, June 1993).

Notwithstanding this increase in interest, one controversy continues to inhibit the development of the research. This relates to the factor structure of union commitment. Although much of the research has relied on Gordon et al.'s (1980) scale to measure union commitment, different studies have uncovered diverse factor structures. The differences in factor structure can only be partially (marginally at best) explained by research varieties in the large number of studies, such as disparate items used, the national contexts of the studies, the statistical methods of analysis, and the nature of the sample. Empirical attempts (such as replications) to solve the debate about dimensionality have also been inconclusive. Given that the development of theory depends crucially on a clear idea of the structure of the construct, this problem merits attention.

The argument in this paper is that the factor structure problem is a theoretical one, stemming from researchers' inability to specify a precise nomological network for union commitment. As Cronbach and Meehl (1955) suggest, the development of a nomological network involves explicitly defining the concepts in the framework, explaining the relations between the different theoretical constructs, and developing propositions of testable relations between the constructs. Therefore, the structure of the construct must flow from a theoretical framework (cf. Bollen. 1989; Walkey and McCormick, 1985). The process of developing a nomological network often also involves efforts to integrate across networks (Roberts, Hulin and Rousseau, 1978).

This paper proposes to develop and test an integrated theory of union commitment in accordance with the principles outlined above. We use different theoretical frameworks to define the nature and structure of union commitment, to specify relations between key theoretical constructs, and to identify testable propositions. The theory is then tested using data from a new sample of Swedish union members. Below, we first discuss the relevant literature, focusing on previous findings. In a subsequent section we describe two new theoretical approaches, and then develop the integrated theory by combining these two approaches. Later sections in the paper deal with descriptions of the sample, methods, and results. 


\section{Conceptual and empirical review}

Based on the literature on organizational commitment (Dubin, Champoux and Porter, 1975; Porter, Crampon and Smith, 1976). Gordon et al. (1980) defined union commitment as the extent to which a person (a) has a strong desire to retain membership in the union, (b) is willing to exert effort for the union, and (c) believes in the objectives of organized labor. Using this definition, Gordon et al. created a commitment scale that empirically yielded four dimensions: Union Loyalty, Willingness to Work for the Union, Responsibility to the Union, and Belief in Unionism.

The four-factor solution suggested by Gordon's theory has been replicated in many studies. Out of 20 different studies addressing the dimensionality of union commitment that we have identified, about half the studies report a similar factor structure of union commitment. However, the remaining studies report differing factor structures, ranging from one to five different dimensions. Table 1 reports these studies.

As Table 1 indicates, there appear to be two major alternatives to the four-factor structure found by Gordon et al. (1980). The first of these is the more parsimonious two-factor solution, suggested by Friedman and Harvey (1986) in their reinterpretation of Gordon et al.'s (1980) data, and by several others (notably, Eaton, Gordon and Keefe. 1992; Kuruvilla. 1989; Kuruvilla and Sverke, 1993). The underlying logic of the two-factor solution is that union commitment is composed of one attitudinal dimension and one behavioral or intentional dimension. These findings are consistent with the theory of reasoned action of Fishbein and Ajzen (1975). The second major alternative is the three-factor solution suggested by Kelloway, Catano and Southwell (1992). While these authors find support for one attitudinal dimension (loyalty) and two intentional dimensions (responsibility and willingness to work for the union), they argue that the Gordon et al. (1980) belief in unionism factor is a consequence of the negative wordings of the items comprising the scale.

The natures and types of dimensions found in the other studies do not exhibit any definite pattern, and include such diverse dimensions as union instrumentality, organization and work loyalty, personal commitment to the union, pride in membership (different from loyalty), shared values, and a general union commitment factor (see Table 1).

Our purpose in this review is to examine the differences across studies in more detail to see whether these differences can adequately explain the divergent factor structures uncovered. However, we should note here that the differences are such that they inhibit our ability to draw firm conclusions. Below, we address both methodological and conceptual problems with previous studies. 


\section{Factor analysis methods}

Table 1. Sample characteristics, methodological issues, and factors found in studies of the dimensionality of union commitment

\begin{tabular}{|c|c|c|c|c|c|c|}
\hline Study & $\begin{array}{l}\text { No. } \\
\text { items }\end{array}$ & $\begin{array}{l}\text { No. } \\
\text { dim }\end{array}$ & Country & $N$ & $\begin{array}{l}\text { Resp. } \\
\text { rate }\end{array}$ & Sample \\
\hline Gordon et al. (1980) & 48 & 4 & U.S. & 1377 & $40 \%$ & White-collar \\
\hline Ladd, Gordon, Beauvais and & & & & & & \\
\hline Morgan (1982) & 47 & 4 & U.S & 783 & $39 \%$ & Prof/white-collars \\
\hline Friedman and Harvey (1986) & $48 / 37 / 30$ & 2 & U.S. & \multicolumn{3}{|c|}{ see Gordon et al. (1980) } \\
\hline Fullagar (1986) & 28 & 5 & S. Africa & 202 & $17 \%$ & Blue-collar \\
\hline Klandermans (1989) & 37 & $2 / 3 / 5 \dagger$ & Netherlands & 128 & $75 \%$ & Blue-collar \\
\hline $\mathrm{Ng}(1989)$ & 12 & 3 & Canada & 456 & $48 \%$ & Faculty \\
\hline Sherer and Morishima (1989) & 7 & 1 & U.S. & 579 & $50 \%$ & Airline carriers \\
\hline Thacker et al. (1989) & 26 & $4(1) \S$ & U.S. & 402 & $88 \%$ & Blue-collar \\
\hline $\begin{array}{l}\text { Tetrick, Thacker and Fields } \\
\text { (1989) }\end{array}$ & 29 & 4 & U.S. & \multicolumn{3}{|c|}{ see Thacker et al. (1989) } \\
\hline Iverson and Kuruvilla (1990) & 18 & 4 & Australia & 181 & $43 \%$ & Blue/white \\
\hline Mellor (1990) & 20 & 2 & U.S. & 555 & $56 \%$ & Blue-collar \\
\hline Savery et al. (1990) & 20 & 4 & Australia & 946 & $34 \%$ & Bank employees \\
\hline \multicolumn{7}{|l|}{ Thacker, Fields and Barclay } \\
\hline \multirow[t]{2}{*}{ Iverson and Kuruvilla (1991) } & 12 & $\begin{array}{l}4 \\
2\end{array}$ & Sweden & $\begin{array}{r}481 \\
1805\end{array}$ & $62 \%$ & Professionals \\
\hline & 11 & 4 & U.S. & 838 & $57 \%$ & Teachers \\
\hline Thacker, Tetrick, Fields and & 26 & 4 & U.S. & 559 & $85 \%$ & Blue/white \\
\hline Rempel (1991) & 26 & 4 & Canada & 121 & $45 \%$ & Blue/white \\
\hline Sverke (1992) & 25 & 3 & Sweden & 116 & $89 \%$ & Blue-collar \\
\hline Eaton et al. (1992) & 21 & 2 & U.S. & 400 & $64 \%$ & Clerical/technical \\
\hline \multirow[t]{2}{*}{ Johnson (1992) } & 9 & 1 & U.S. & 145 & $71 \%$ & Federal government \\
\hline & 9 & 2 & U.S. & 234 & $48 \%$ & Blue-collar (private) \\
\hline Kelloway et al. (1992) & 13 & 3 & Canada & 925 & $34 \%$ & Blue/white \\
\hline \multirow[t]{2}{*}{ Kuruvilla and Sverke (1993) } & 10 & 2 & Sweden & 1914 & $66 \%$ & Professionals \\
\hline & 10 & 2 & U.S. & 1088 & $45 \%$ & Letter carriers \\
\hline
\end{tabular}

* EFA $=$ Exploratory Factor Analysis, CFA $=$ Confirmatory Factor Analysis.

† Klandermans extracted five factors. While he did not interpret all five, he recommended the use of only the first two. $\ddagger$ Originally a dual commitment study, where company commitment was Factor 1 and union commitment Factor 2. $\S$ Although Thacker $e t$ al. identified all four of Gordon $e t$ al.'s (1980) factors, they also concluded that a composite union commitment measure could be used.

I The article is made up of two studies, where Study 2 is a replication of findings from Study 1. All figures in the table refer to Study 2.

The studies in Table 1 are primarily of two kinds: those that have used exploratory factor analysis (EFA) and those that have used confirmatory factor analysis (CFA). In particular we are interested more in the CFA studies, since they test alternate factor structures to find the best fitting model, thus providing a potential empirical solution to the dimensionality debate. Amongst the CFA studies, Thacker, Fields and Tetrick (1989) find support for either a four factor or a single-factor structure. Kelloway et al. (1992) for a three-dimensional structure, and Iverson and Kuruvilla (1991) for a two-dimensional solution. Klandermans (1989), in testing and evaluating different combinations amongst the four factors, ultimately finds support for two robust factors, a loyalty dimension and a willingness dimension that demonstrated internal consistency and construct validity. Therefore, the CFA studies indicate support for a more parsimonious dimensionality of commitment. 
It is also important to note that there has been variation in the methods of factor rotation that were used. Most studies treated the factors as being orthogonal, while some studies allowed for factor intercorrelation using oblique transformation. While the method of rotation does not determine the number of dimensions per se, it influences the factor structure, i.e. the sizes and patterns of factor loadings (cf. Thurstone, 1947). The rotation method thus has an effect on the interpretation and labelling of dimensions but, given lack of data, we cannot make a case for this feature being a major explanation for differing factor structures.

Finally, there have been differences in the subjective interpretation of the factors, and in the nomenclature used, that make it difficult to draw firm conclusions when comparing the factors across studies.

\section{Number of items}

Virtually all the studies use subsets of the Gordon et al. (1980) scale. In some cases, it is possible to relate the number of items to the number of factors. For instance, using !0 items Kuruvilla and Sverke (1993) report only two factors, but that is not surprising given that their items were constructed such that only two factors would emerge; their theory suggested only two factors of commitment. Further, several studies using 25 items or more find support for a four-factor solution. But there are other studies that use a substantial number of Gordon et al.'s (1980) items, yet showing differing factor results (e.g. Fullagar. 1986; Klandermans. 1989; Savery, Soutar and Dufty. 1990). As Table 1 indicates, studies with as many as 11 items support a four factor solution (e.g. Iverson and Kuruvilla, 1991), while studies with as much as 20 items or more show support for only two factors (e.g. Eaton et al., 1992; Mellor, 1990). The first-order correlation between the number of items and the number of factors, using the 20 studies in Table 1, is positive and significant $(r=0.60, p<0.05)$ however.

Aside from the number of items, the choice of items in the questionnaire also differs across studies. While it is clear that most studies used items derived from the Gordon et al. (1980) scale, they have used a smaller number of items and some of the items have been different (e.g. Iverson and Kuruvilla, 1990; Johnson, 1992; Savery et al., 1990). The rationale for the choice of items is often absent and, in some cases, their psychometric properties are not known. What is interesting is that some of the 'home-grown' scales, though different from Gordon's, also demonstrate support for the fourdimensional solution (e.g. Iverson and Kuruvilla, 1991). This may be due to the fact that these researchers just employed shortened versions of the Gordon scale, using only the items that have high 
loadings due to constraints of space in their questionnaire, or have made minor modifications in the scale based on local conditions, or have changed items at the request of the unions participating in the study. Where the scale has been constructed based on a selective subset of the Gordon et al. (1980) items, the studies have contributed to the development of a more parsimonious set of items. On the other hand, the differences in scales used make it difficult to compare the factor structure of union commitment across studies.

\begin{tabular}{|c|c|c|c|c|c|}
\hline $\begin{array}{l}\text { Method } \\
\text { used* }\end{array}$ & 1 & 2 & $\begin{array}{c}\text { Factors found } \\
3\end{array}$ & 4 & 5 \\
\hline EFA & Loyalty & Responsibility & Willingness & Belief & \\
\hline EFA & Loyalty & Responsibility & Willingness & Belief & \\
\hline EFA/CFA & Att \& Op. & Intentions & & & \\
\hline $\begin{array}{l}\text { EFA } \\
\text { EFA }\end{array}$ & $\begin{array}{l}\text { Loyalty } \\
\text { Loyalty }\end{array}$ & $\begin{array}{l}\text { Responsibility } \\
\text { Willingness }\end{array}$ & Org./work loy. & Belief & Instrumentality \\
\hline EFA & Loyalty & Willingness & Responsibility & & \\
\hline EFA & UC: & & & & \\
\hline CFA & Loyalty & Responsibility & Willingness & Belief & \\
\hline CFA & Loyalty & Responsibility & Willingness & Belief & \\
\hline CFA & Loyalty & Responsibility & Willingness & Belief & \\
\hline EFA & Att \& Op. & Intentions & & & \\
\hline EFA & Loyalty & Willingness & Pride & Personal UC & \\
\hline EFA & Loyalty & Responsibility & Willingness & Belief & \\
\hline $\begin{array}{l}\text { CFA } \\
\text { CFA }\end{array}$ & Att \& Op. & Intentions & & & \\
\hline CFA & Loyalty & Responsibliity & Willingness & Belief & \\
\hline $\begin{array}{l}\text { CFA } \\
\text { CFA }\end{array}$ & Loyalty & Responsibility & Willingness & Belief & \\
\hline CFA & Loyalty & Responsibility & Willingness & Belief & \\
\hline $\begin{array}{l}\text { EFA } \\
\text { PC/CFA }\end{array}$ & $\begin{array}{l}\text { Identity } \\
\text { Lovalty }\end{array}$ & Loyalty & Shared values & & \\
\hline $\begin{array}{l}\mathrm{PC} / \mathrm{CFA} \\
\mathrm{EFA} / \mathrm{CFA}\end{array}$ & $\begin{array}{l}\text { Loyalty } \\
\text { UC }\end{array}$ & Responsibility & & & \\
\hline EFA/CFA & Loyalty & Willingness & & & \\
\hline CFA & Loyalty & Willingness & Responsibility & & \\
\hline CFA & Att \& Op. & Intentions & & & \\
\hline CFA & Att \& Op. & Intentions & & & \\
\hline
\end{tabular}

Sample characteristics

The sample characteristics also vary considerably. Nine out of the studies listed in Table 1 focused primarily on blue-collar workers, with differing factor structures. The other studies focused on whitecollar workers (three studies), professionals (two studies), faculty, teachers, airline carriers, bank employees, and federal government employees in the U.S.A. (one study each). Our investigation does not suggest any clear relationship between the type of sample and the number of dimensions. The 
sample sizes also differ, ranging from 116 to 1805, although the impact of sample size on the number of factors is less direct.

National contexts

The studies have been done in a variety of national contexts of industrial relations systems. Fourteen of the studies in Table 1 used samples from the U.S., while other studies used samples from Australia (two), Canada (three), three Netherlands (one). South Africa (one), and Sweden (three). These countries are characterized by significant differences in industrial relations systems, with differences in union goals, functions, and structure, as well as in the labor management relations climate. These differences raise the possibility that the cultural setting may have influences on the factor structure of commitment that is found. However, no clear pattern is apparent in the results that would lend support for a 'national type" effect.

\section{Response rates}

The range of response rates in the union commitment studies is wide, ranging from a low of 17 per cent to a high of 89 per cent, with the mean response rate being 57.5 per cent. We do not know how response rates affect the factor structure in these studies. Since members may interpret the completion of a union survey as a different form of union participation (Kelloway and Barling, 1993), low response rates would imply that only committed members participated in the survey, providing some bias in the reported means and, perhaps, in the factor structure.

\section{Conceptual issues}

One conceptual problem with union commitment relates to the Gordon et al. (1980) belief in unionism factor. This dimension has been found to be the weakest factor in terms of construct validity and internal consistency in many studies, including some of the studies that support a four-factor solution. Moreover, belief in unionism has invariably been found to be correlated weakly with the other factors in most studies.

The way this dimension has been specified in Gordon's definition raises an important issue, namely, what should be the appropriate focus of union commitment. Although Gordon et al.'s (1980) 
definition of union commitment followed the Porter et al. (1976) definition of commitment, it differed from that definition in one aspect, i.e. the focus. While the original definition of organizational commitment (Dubin et al., 1975; Mowday, Steers and Porter, 1979; Porter et al., 1976) suggests a belief in the goals of the specific organization that the employee works for, Gordon et al. (1980) defined belief in terms of belief in unionism as a whole, or beliefs in unionism in general.

This, we feel, is an important conceptual problem. It is essential for researchers to focus on members' commitment to their local union, and not to unionism in general, or an abstract concept of unionism per se. Focusing on unionism in general implicitly assumes that all unions have exactly similar goals, which is not true. The specific union is the focus of the construct. Note that in models that examine the antecedents of various commitment factors (e.g. Iverson and Kuruvilla. 1993), most local union-specific predictors explain a significant percentage of the variance in the union loyalty, responsibility, and willingness to work factors, but seem relatively unrelated to the belief in unionism factor. Therefore, we argue that the belief in unionism dimension found by Gordon et al. (1980) does not flow from the theory that was used as the basis for the development of the scale, since it does not deal with the union to which the member is attached. Klandermans (1989) makes the same point as well in his analysis, while Kelloway et al. (1992) raise the possibility that the belief in unionism dimension is an artefact resulting of negatively worded items.

\section{Summary}

In summary, this brief literature review suggests that the empirical differences across studies are large enough to inhibit our ability to effectively address the union commitment dimensionality debate. Conceptually, there is a problem with the belief in unionism dimension. Most importantly, the existing theoretical basis underlying the four-factor solution has not been able to reconcile the differences in union commitment dimensions across different studies. Yet, research on union commitment has gone well beyond the dimensionality issue towards studies of antecedents and consequences of individual constructs such as union loyalty (see e.g. Fullagar and Barling, 1989). Clearly, as several authors have suggested (Friedman and Harvey, 1986; Gallagher and Strauss, 1991), additional theory development is warranted to solve the dimensionality debate.

Given the advances being made in union commitment research, we argue that it is critical now to focus on theory development to solve the dimensionality problem. We suggest, further, that new theory development should take the principles of developing nomological networks into account, and 
specify concrete definitions of the constructs and of how the dimensions relate to each other (the current theoretical basis does not specify the relations between different dimensions). The advantage of a theory about the dimensionality of union commitment is that it will provide a stable basis against which differences in factor structures over different studies can be assessed. In the next section, we describe two different theoretical approaches to union commitment. We also evaluate the existing empirical support for these theories, and propose a new theory based on the integration of the theories.

\section{Two alternative theoretical approaches to union commitment}

Below, we present two alternative theories regarding union commitment. The first of these is the theory of reasoned action, developed by Fishbein and Ajzen (1975), suggested for use in union commitment by Friedman and Harvey (1986). The second theory is the rationalistic approach to union commitment, developed by Sverke and Abrahamsson (1993). It is not our purpose here to formally test these two theories, given that they have already been tested by Kuruvilla and Sverke (1993) and Sverke and Kuruvilla (1993); we refer the reader to these publications for the results. Our primary concern in this section is to integrate these two theoretical approaches, i.e. to combine the two nomological networks to an integrated theory of union commitment.

Theory l: the theory of reasoned action

The theory of reasoned action (Ajzen and Fishbein, 1980; Fishbein and Ajzen, 1975) focuses on understanding the information processes that underlie attitude formation and, through that, to understanding why people behave in certain ways. Fishbein and Ajzen base their model of reasoned action on the distinction drawn between the three components of any attitudinal construct, i.e. affect, cognition, and conation (Allport, 1935). In the Fishbein and Ajzen framework, these components translate into beliefs, attitudes and intentions. Fishbein and Ajzen (1975; see also Ajzen and Fishbein, 1980) have shown that these three components, although related, are distinct from each other, are influenced by different variables, and are differentially related to outcome variables, i.e. that they evidence discriminant validity.

Fishbein and Ajzen (1975) also suggest a pattern of causal relations between the three components. Briefly, their theory posits that a person's salient beliefs about various objects, actions, or events lead to the formation of attitudes towards that object, action or event. Beliefs themselves are 
formed, and modified, by exposure to information that either creates new beliefs or modifies existing ones. Once an attitude is formed about an object, action, or event, the attitude leads to the formation of behavioral intentions with respect to that object, action, or event. Behavioral intentions, then, lead to actual behavior. But, according to the theory of reasoned action, behavioral intentions are affected not only by attitudes, but also by subjective norms (perceived expectations of referents important to the individual, and the individual's motivation to comply with those expectations). In this framework, hen intentions are proposed to cause behavior, while attitudes and subjective norms are suggested to influence behavior only through the behavioral intentions.

However, Fishbein and Ajzen (1975) advanced the idea that measures of beliefs will often yield results similar to direct measures of attitudes since, in most studies, beliefs and attitudes are assessed by direct self-reports. As suggested by Bem (1965. 1972), since measures of beliefs and attitudes are usually self-descriptive verbal responses, and since these responses are influenced by both external and internal stimuli (e.g. the person's beliefs and behaviors as well as the context in which these occur), in effect, the beliefs and attitudes that an outsider would attribute to an individual are, therefore, functionally equivalent in that both sets of statements are inferences from the same evidence. Consequently, as long as the assessment instruments use self-report measures, there are only two components to an attitude in practical terms: beliefs/attitudes and behavioral intentions.

Since union commitment has been conceptualized as an attitude, it appears reasonable to apply the model of reasoned action to the study of the construct. The application (see Kuruviila and Sverke (1993) for more specifics on details regarding the application) of the theory of reasoned action to the dimensionality of union commitment has several advantages. First, the theory specifies the number of dimensions of the concept (two, i.e. union attitudes/opinions and pro-union behavioral intentions) and, second, suggests how these two dimensions are causally related. Third, the theory suggests that only one dimension (i.e. intentions) is important in predicting behavior. Fourth, the theory also guides us regarding the selection of variables that are likely to influence the development of union attitudes, such as normative beliefs and information sources. Finally, the theory incorporates the factor of beliefs about the specific union as part of the attitudinal dimension, also suggesting that it is beliefs about the particular union, and not unionism in general, that is important. A schematic representation of the Fishbein and Ajzen framework translated to the union commitment context is presented in Figure 1. 


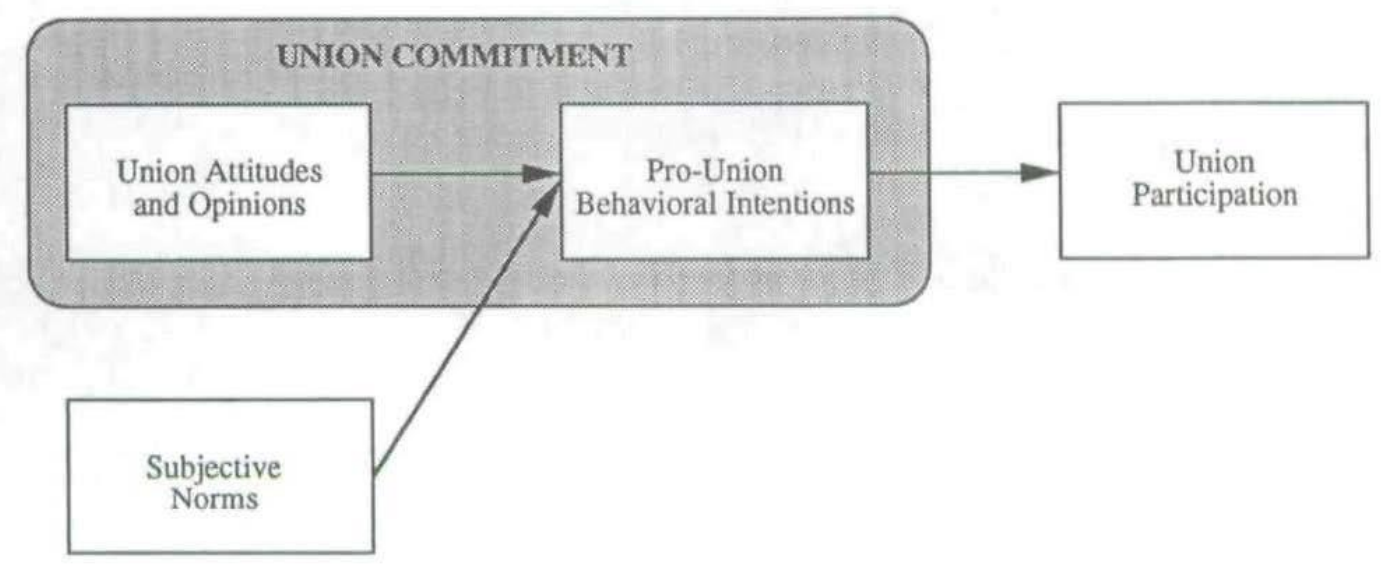

Figure 1. A model of commitment and participation based on the theory of reasoned action

There is some support for the theory in the union commitment literature. Friedman and Harvey (1986) suggest that their two-dimensional solution to union commitment is consistent with the theory, while the results of both Klandermans (1989) and Mellor (1990) are also in concordance with the theory. Kuruvilla and Sverke (1993) find support for the theory in their empirical investigation of union commitment dimensionality. In addition, Kuruvilla, Gallagher and Wetzel (1993) have used the theory to identify several important antecedents of union commitment in their studies in Sweden and Canada, while Kelloway and Barling (1993) have used a modified version of the theory in a study of union commitment and participation.

Theory 2: the rationalistic approach to commitment

A different approach is taken by Sverke and Abrahamsson (1993), who argue that union commitment can best be described in terms of two dimensions derived from Weber's (1968) theory of social action. Weber distinguishes two rational ways in which social action can be oriented. It may be instrumentally rational, i.e. 'determined by expectations as to the behavior of objects in the environment and of other human beings; these expectations are used as "conditions" or "means" for the attainment of the actor's own rationally pursued and calculated ends' $(1968$, p. 24$)$. Social action may also be value rational, i.e. 'determined by a conscious belief in the value for its own sake of some ethical, aesthetic, religious, or other form of behavior, independently of its prospects of success' (1968, pp. 24-25)i.

According to Weber, an action is rational when it (a) is oriented by a consciously, unambiguously formulated goal or value, and (b) uses the means which, according to available knowledge, best lead to the realization of the goal or value. Rationality is thus defined in terms of the actor, which means that an 
action can be rational even if the actor, owing to a lack of knowledge, has not chosen the objectively most proper means to realize the goal or value. Therefore, in the context of union commitment, one may expect to see two dimensions, an instrumental-rational dimension and a value-rational dimension. Figure 2 presents a model of union commitment and participation as suggested by the rationalistic approach.

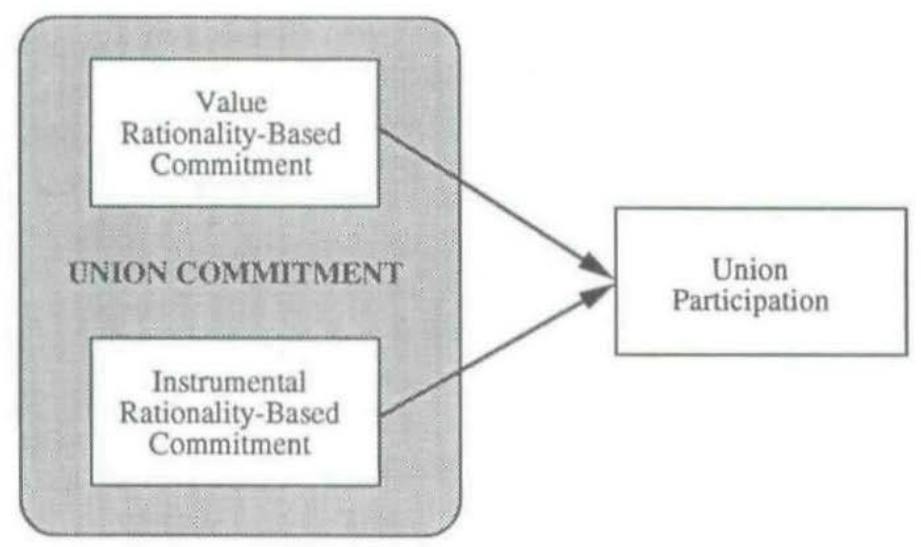

Figure 2. A model of commitment and participation based on the rationalistic approach

Sverke and Abrahamsson (1993) proposed that instrumental rationality-based commitment to the union reflects a utilitarian relationship between members and unions, where the individual member is attached to the union mainly because of the union's instrumental value to the member. The degree of instrumental rationality-based commitment is thus dependent upon conscious assessments of costs and benefits associated with membership. The idea of exchange, which is at the root of this conceptualization, is consistent with the approach of rational choice theorists (e.g. Olson. 1971). It is also consistent with the notion of calculative commitment, extensively used in the organizational literature (e.g. Becker, 1960; Hrebiniak and Alutto, 1972) as well as with that of exchange which underlies the loyalty dimension of the Gordon et al (1980) scale.

The value-rational dimension on the other hand, refers to the degree of value congruence between the member and his/her union. It is the perceived identification of the member with the content oftho.se particular ends to which an action is oriented (cf. Weber, 1968, p. 25). In the case of the union, a non-utilitarian union ideology is often necessary for collective action to take place \{cf. Offe and Wiesenthal. 1980). In other words, a member is value-rationally committed if the goals of the union are consistent with his or her values. In contrast to the instrumental dimension, value rationality-based commitment to the union is not likely to vary with the short-term gains made by the union, but is more long-term and stable. The concept of value rationality is consistent with approaches 
in the organizational literature also. For example, Enz (1988), Schein (1985), and Selznick (1957) have acknowledged the role of values in organizational functioning and highlighted the importance of creating social structures based on organizational values.

An essential part of Weber's (1968) conceptualization is that both types of rationality are important, since social action is not always based on expectations of individual gain; often individuals organize in the work for an ideological cause (Abrahamsson, 1993b; cf. Sen, 1982). This formulation suggests, then, that commitment to the union can develop both (1) as a consequence of perceptions that the benefits of being a member exceed the costs of belonging to the union, and (2) as a function of what the individual member perceives the union to represent, regardless of the consequences for individual utility.

Another significant advantage of the rationalistic approach is that this conceptualization makes it possible to better reflect union commitment in different cultural contexts, i.e. where unions differ significantly in terms of their orientation, such as in union environments characterized by varying degrees of business unionism and welfare unionism. It is postulated that both value rationality and instrumental rationality can be potential sources of member attachment to the union, but that the relative impact on subsequent membership behaviors of each commitment dimension may vary from country to country or setting to setting ${ }^{\text {ii }}$.

In recent years, researchers have underlined the importance of studying non-instrumental factors in members' attachment to their unions (e.g. Fiorito 1992; Gordon and Ladd 1993; Newton and Shore, 1992; Sverke and Abrahamsson, 1993; Sverke and Kuruvilla, 1993). The distinction between instrumental and value-based attitudes has been used also in other areas of research on unions (e.g. Child, Loveridge and Warner. 1973; Freeman and Medoff, 1984; Offe and Wiesenthal, 1980). For example, Goldthorpe, Lockwood, Bechofer and Platt (1968) distinguished job conscious unionism (a term used to describe union members for whom the support for the union is purely calculative) and political unionism (representing members having internalized union values and traditions). Spinrad (1960) noted that participation in union activities is not only a function of union instrumentality, but also of value congruence between members and union.

Instrumental and ideological dimensions have been distinguished in the area of organizational commitment as well. For instance, the notion of identification with organizational values plays a central role in the terms 'control commitment' (Kanter, 1968), 'normative commitment' (Wiener, 1982), and 'internationalization' (Kelman, 1958; O'Reilly and Chatman, 1986). The distinction between instrumental and non-instrumental attitudes is apparent also in Etzioni's (1975) propositions on 
involvement in organizations; according to Etzioni, involvement ranges from alienation (negative) over calculative involvement (neutral) to moral involvement (positive, i.e. commitment). However, rather than being a question of degree in one variable as suggested by Etzioni, involvement in an organization can most fruitfully be seen as composed of two independent variables: instrumental rationality and value rationality (Sverke and Abrahamsson, 1993).

Although it has been argued that the term commitment should not be used for both instrumentality perceptions and ideological beliefs (e.g. Newton and Shore, 1992; Wiener, 1982), we retain the term since it reflects the common denominator underlying both conceptualizations. Commitment refers to a psychological state binding the individual to the organization regardless of the nature of the psychological state (Allen and Meyer, 1990). Both dimensions of union commitment proposed by the rationalistic approach range from low (representing a negative attitude toward the union, i.e. non-commitment) to high (representing a positive attitude, i.e. commitment).

In terms of union commitment, the theory not only suggests two attitudinal constructs, but postulates (Sverke and Abrahamsson, 1993) that value rationality-based commitment is a stronger predictor of union participation as compared to instrumental rationality-based commitment. Members expressing instrumental commitment could be expected to remain members (in cultures where that is an option) and to take part only in such union activities that involve little time and personal sacrifice; they will receive the same benefits whether they participate or not $\{c f$. the logic of collective action advocated by Olson, 1971). Value-rationally committed members are likely to be the ideological, voluntary activists the union needs to perform the daily tasks (cf. Goldthorpe et al., 1968; Offe and Wiesenthal. 1980; Thompson, 1967). Thus, although members committed primarily on an instrumental rationality basis as well as members committed primarily on a value rationality basis could both be expected to retain membership and to support certain union activities, the rationales underlying their retention and support reflect varying natures of responsibility associated with membership and, hence, will be markedly different (Sverke and Abrahamsson, 1993).

The one empirical test of this theory is the study conducted by Sverke and Kuruvilla (1993). Results of a confirmatory factor analysis on a standard union commitment questionnaire provide strong empirical support for the two dimensions of union commitment proposed by the rationalistic approach. The constructs were found to be distinct and to exhibit discriminant validity. In addition, value rationality-based commitment was found to be a stronger predictor of various behavioral intentions with respect to the union. 
Integration of the two theories

Both theories discussed have been empirically tested and found to be supported. They are also consistent with several approaches in both organizational and union literatures. The integration of the two theories is guided by the following assumptions: (1) union commitment is an attitudinal construct and, by definition (e.g. Allport, 1935), an attitude is composed of different parts; (2) an attitude, however, also consists of a process and an outcome; (3) the key aspect of studying attitude is ultimately to predict behavior and, therefore, any theory of attitude must specify the causal links between attitudinal and behavioral components. Combining the two theories makes it possible to articulate a new theoretical framework that meets the criteria of a nomological network, and satisfies the assumptions noted above.

A fundamental underpinning of this unified framework is the assumption that individuals are 'usually quite rational and make systematic use of the information available to them .../They/ consider the implications of their actions before they decide to engage or not engage in a given behavior' (Ajzen and Fishbein, 1980, p. 5). A second underpinning, drawn from rationalistic organization theory (e.g. Abrahamsson, 1993a, b), is that an organization is an instrument to realize certain interests; individuals' rational strivings to realize certain goals or values are assumed to give rise to collective, organized action. The key question here is on what rational grounds (instrumental or value rationality) individuals decide to engage in such collective action.

Commitment may be viewed as 'the process through which individual interests become attached to the carrying out of socially organized patterns of behavior' (Kanter, 1968, p. 500). According to the definition of commitment suggested by the rationalistic approach, attitudes of union commitment involve reasoning; it should follow, then, that any effect which union commitment has on members' behavior and participation in union activities is a form of reasoned action.

The integration of the theory of reasoned action with the rationalistic approach to commitment allows us to specify (a) the structure, i.e. the number of dimensions, of the union commitment construct, and 
also (b) how the dimensions are causally related, essential conditions for a nomological network.

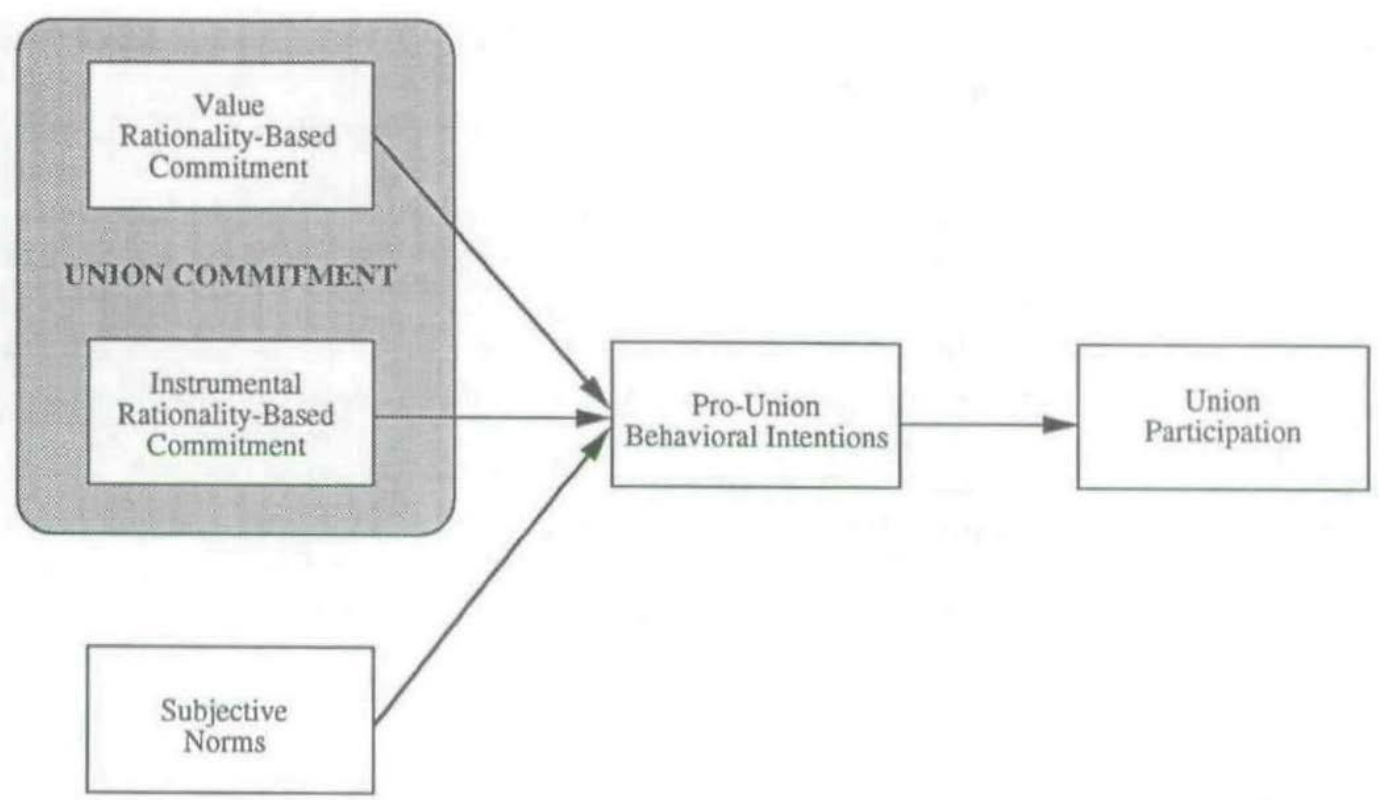

Figure 3. A model of commitment and participation based on the integrated theory

The Fishbein and Ajzen (1975) theory identifies two dimensions of commitment, i.e. attitudes and intentions, with attitudes causally related to intentions. The Sverke and Abrahamsson (1993) theory identifies two attitudinal dimensions, one based on instrumentality and one based on values. Incorporating the Sverke and Abrahamsson theory into the Fishbein framework essentially involves splitting the attitudinal part suggested by the theory of reasoned action into two sub attitudinal constructs, value rationality-based commitment and instrumental rationality based commitment. Therefore, the model derived from the integration of the theories will show two attitudes of commitment leading to behavioral intentions, which in turn lead to actual participation. Consistent with the integrated framework, the model also shows that subjective norms influence behavioral intentions. Figure 3 presents a model of union commitment and union participation as suggested by the integrated theory.

Although Fishbein and Ajzen (1975) hypothesize that subjective norms are predictive of all kinds of behavioral intentions, there is much previous research (e.g. Hom, Katerberg and Hulin, 1979; Kelloway and Barling, 1993; Montgomery, 1989) that has shown that subjective norm is a weaker predictor of intentions as compared to attitude. Therefore, one implication of the integration of the two theories is that the two attitudinal dimensions will be stronger predictors of behavioral intentions than will the subjective norms. 
The theory of reasoned action allows for studying specific as well as general intentions as long as the intentions correspond to the level of generality or specificity of the behavioral criterion (Ajzen and Fishbein, 1980). In many situations there is a clear advantage to be able to study different intentions separately, for instance, to retain membership, to strike, to take active part in the union work, and to hold union office. In other cases, particularly in studying the general willingness to work for the union (Kuruvilla and Fiorito, in press), it is better to combine several specific union-related intentions into one general intention dimension. In the integrated theory, we treat pro-union behavioral intentions (like actual union participation) as an outcome of commitment. However, the theory provides researchers with the flexibility to study both specific and general intentions within the same framework. The integrated theory, therefore, yields the following testable propositions:

(1) Instrumental and value rationality-based commitment are two distinct constructs.

(2) Value rationality-based union commitment predicts all types of pro-union behavioral intentions.

(3) Instrumental rationality-based union commitment predicts such pro-union behavioral intentions that involve little personal effort and sacrifice (e.g. the intention to remain a union member).

(4) Subjective norms predict all types of pro-union behavioral intentions.

(5) The attitudinal variables (i.e. commitment dimensions) will be stronger predictors of behavioral intentions than will the subjective norms.

(6) Value rationality-based commitment to the union is the strongest predictor of all kinds of pro-union behavioral intentions.

(7) The pro-union behavioral intentions are strongly and positively related to subsequent behaviors.

(8) Attitude and subjective norm predict behavior only indirectly, via the behavioral intentions.

\section{Methods}

Subjects and data collection procedure

The data were collected in the first wave of a Swedish longitudinal research project on emerging union structures. Two per cent of the members of three blue-collar unions (the Swedish Clothing Workers Union, the Swedish Food Workers Union, and the Swedish Factory Workers Union) affiliated to the Swedish Trade Union Confederation (LO) were sampled in September 1991. A total of 2831 questionnaires were mailed to the homes of the union members. A cover letter explaining the purpose 
of the project was included with each questionnaire, with assurances that the data would be kept confidential. In addition, a letter from the president of participants' respective union requesting members to cooperate with the survey was also included. The subjects were asked to return the questionnaires to the research team in the self-addressed, reply paid envelopes that were provided. Up to four reminder letters were sent to those who had not returned their questionnaires. A total of 1684 questionnaires were returned, resulting in a response rate of 59.5 per cent. After case-wise deletions for missing values, 1486 questionnaires were usable for analysis.

The mean age of the respondents was 38.7 years $(S . D .=13.0)$ and their mean union and company tenure were $11.1(S . D .=9.9)$ and $9.9\{$ S.D. $=8.9)$ years respectively. Fifty-one per cent of the subjects were men. Given the low response rate, it was felt necessary to examine whether nonrespondents differed systematically from respondents. Telephone interviews conducted with 5 per cent of the non-respondents revealed few differences between respondents and non-respondents. The only area of difference, interestingly, was in terms of the mean on value rationality-based commitment, where non-respondents reported slightly higher means (2.46 for respondents and 2.95 for nonrespondents; $F[1,1496]=5.68 ; \mathrm{p}<0.05)^{\mathrm{iii}}$. In addition, it was found that a larger percentage of the respondents attended union meetings (respondents 54.95 per cent; non-respondents 36.84 per cent; $\left.x^{\wedge} 2[1]=4.90 ; p<0.05\right)$. However, a comparison based on archival data provided by the unions revealed that the three sub-samples did not differ significantly from their respective unions in terms of age and gender. (For a detailed description of the analysis of non-respondents, see Sverke and Netrell, 1993).

Table 2. First-order correlations, reliabilities (alphas), means, and standard deviations for all variables in the study

\begin{tabular}{lccccccccccc}
\hline & 1 & 2 & 3 & 4 & 5 & 6 & 7 & 8 & 9 & 10 & 11 \\
\hline 1. Value rationality-based UC & & & & & & & & & & & \\
2. Instrumental rationality-based & & & & & & & & & & & \\
UC & 0.66 & & & & & & & & & & \\
3. Subjective norm & 0.46 & 0.38 & & & & & & & & & \\
4. Membership intention & 0.57 & 0.46 & 0.32 & & & & & & & & \\
5. Activity intention & 0.59 & 0.39 & 0.28 & 0.26 & & & & & & & \\
6. Altruistic intention & 0.33 & 0.21 & 0.16 & 0.15 & 0.30 & & & & & & \\
7. Union office intention & 0.40 & 0.29 & 0.19 & 0.15 & 0.51 & 0.20 & & & & & \\
8. Strike intention & 0.13 & 0.10 & 0.04 & 0.23 & 0.02 & 0.01 & 0.07 & & & & \\
9. Administrative participation & 0.32 & 0.13 & 0.14 & 0.13 & 0.29 & 0.10 & 0.26 & 0.12 & & & \\
10. Occasional participation & 0.30 & 0.09 & 0.15 & 0.09 & 0.32 & 0.10 & 0.29 & 0.09 & 0.55 & & \\
11. Supportive participation & 0.34 & 0.15 & 0.20 & 0.12 & 0.34 & 0.12 & 0.31 & 0.10 & 0.45 & 0.64 & \\
Mean & 2.47 & 3.34 & 3.04 & 3.95 & 2.25 & 2.16 & 1.72 & 4.01 & 1.19 & 1.24 & 1.50 \\
S.D. & 0.94 & 0.67 & 0.96 & 1.21 & 1.21 & 1.31 & 1.17 & 1.29 & 0.35 & 0.34 & 0.29 \\
Alpha & 0.91 & 0.86 & 0.80 & 0.84 & - & - & - & - & 0.74 & 0.72 & 0.70 \\
\hline
\end{tabular}

For $r \geqslant 0.07, p<0.01 ; r \geqslant 0.09, p<0.001$.

Scales for variables 1 to 8 range from 1 to 5 , and for variables 9 to 11 from 1 to 2 . 
Measures

Descriptive statistics (means, standard deviations, reliabilities) for all variables and first-order correlations between variables are presented in Table 2 . Unless stated otherwise, responses on all items were made on five-point Likert-type scales ranging from I (strongly disagree) to 5 (strongly agree). Reversed items were recorded prior to index construction. In order to facilitate comparisons between scales, indices were constructed by summing the responses on items and, then, dividing by the number of items.

\section{Union commitment}

Value rationality-based commitment to the union was measured by a nine-item scale developed by Sverke and Sjoberg (1994) (alpha = 0.91). Instrumental rationality-based commitment was measured by seven items derived in accordance with Fishbein and Ajzen's (1975) definition of attitude, and was found to have high reliability (alpha $=0.86$ ). A description of the items used, with their factor loadings, are provided in the Appendix.

\section{Subjective norms}

To assess subjective norms, we followed Fishbein and Ajzen's (1975) definition, which has also found use in studies of union commitment and participation (Fullagar, McCoy and Schull, 1992; Kelloway and Barling, 1993). Since subjective norms in the Fishbein and Ajzen framework are composed of two components, a normative belief and the motivation of the respondent to comply with that normative belief, we used two different scales to measure each of these aspects. In case of normative beliefs, respondents rated, on a five-point scale, the extent to which important referent groups (co-workers, friends, and family members) wanted them to be union members. The motivation to comply with the expectations of important referents was measured by items to which the respondent indicated (on a five-point scale; 1 = not very much, 5 = very much) the extent to which he/she wished to comply with each of the referents' expectations. The overall subjective norms scale was then calculated by multiplying each normative belief by its corresponding motivation to comply item. In order to equalize 
this scale with the other scales used, the square roots of the products were employediv. The resulting three-item scale evidenced an acceptable range of reliability (alpha $=0.80$ ).

\section{Pro-union behavioral intentions}

Since we, consistent with the theoretical framework, proposed to study both general and specific intentions, several different intention scales were created. Five types of pro-union behavioral intentions were used in the present study. A three-item scale was used to measure union membership intention, i.e. the intention to remain a union member (alpha $=0.84)$. Activity intention, i.e. the intention to take an active part in the daily union work, was measured by a single item. Single items were also used to measure union office intention ('If asked, I would run for an [additional] elected office in the union'), strike intention ('If my union called a strike, I would absolutely not join it'), and altruistic intention ('If my union wanted it. I would dispense with a salary increase to support low-paid members of other unions').

\section{Union participation}

Three scales developed by the authors and reflecting varying natures of participation (administrative participation, occasional participation, and supportive participation; $c f$. McShane. 1986; Nicholson. Ursell and Lubbock, 1981) were used in this study ${ }^{v}$ Items were coded I = no and $2=y e s$, summed, and divided by the number of items to create participation scales. Administrative participation was measured by two items asking whether the respondents had any representative position in the union (alpha $=0.74)$. Occasional participation was measured by four items where the respondents were asked to indicate whether they during the last year had, for instance, attended meetings and taken part in bargainings (alpha $=0.72$ ). Supportive participation was assessed with a six-item scale reflecting respondents' last year participation in activities such as attending a union study circle, discussing union issues with colleagues, discussing union issues with union representatives, and reading through the collective agreement (alpha $=0.70)$.

\section{Analytical issues}

Based on the integrated theory and the model in Figure I. a structural equation model of union commitment was specified using the maximum likelihood methods of LISREL 7 (Jöreskog and Sörbom, 
1989). We used structural equation modelling since this technique provides a means for operationalizing concepts in nomological networks (Bentler, 1980) and for hypothesis testing (Breckler. 1990). The maximum likelihood procedure provides statistical indicators of the goodness-of-fit for the model generally as well as standard error estimates for individual parameters in the model. Thus, model-data consistency can be checked both via an evaluation of the overall model and by comparing the magnitude, sign, and statistical significance of parameter estimates to those hypothesized (Bollen, 1989. p. 68). Other major advantages of this procedure are that it relaxes the assumptions that all variables have perfect reliability, that residuals are uncorrelated, and that the causal flow is recursive. Therefore, the procedure adds considerable precision to the estimation of the causal model by correcting for attenuation in random measurement error.

LISREL produces a structural model and a measurement model. The structural model (often referred to as the causal model; Bentler, 1980), tests the hypothesized causal relationships amongst the latent constructs, whereas the measurement model actually is a confirmatory factor analysis of hypothesized relationship between latent (unobserved) constructs and manifest (observed) variables.

The measurement model was specified such that the nine value rationality-based items, the seven instrumental rationality-based items, and the three subjective norm items were constrained to load only on their respective exogenous latent variables. For the endogenous variables, we used the intention and participation scales as indicators. Accordingly, the three participation scales (administrative, occasional, and supportive participation) were constrained to load on the union participation variable, while the four activity-oriented intention scales (activity, office, strike, and altruistic intentions) were constrained to load on the latent pro-union behavioral intentions variable, since we wanted a measure of a general behavioral intention to participate ${ }^{\mathrm{vi}}$.

In case of the structural model, all three exogenous variables were constrained to be predictive only of the pro-union behavioral intentions variable. Amongst the endogenous variables, only the parameter for the effect of pro-union behavioral intentions on union participation was estimated. These specifications enable us to test the various propositions generated by the integrated theory.

Throughout the analysis, standardized results are presented in order to make comparisons across parameter estimates. Standardization (rescaling the variances of the latent variables to unity) also makes the endogenous factor residuals interpretable as the proportion of unexplained variance, i.e. variance not accounted for by the other model variables. Since maximum likelihood estimation is scale invariant, standardization has no adverse effect on statistical tests made (Bollen, 1989). 


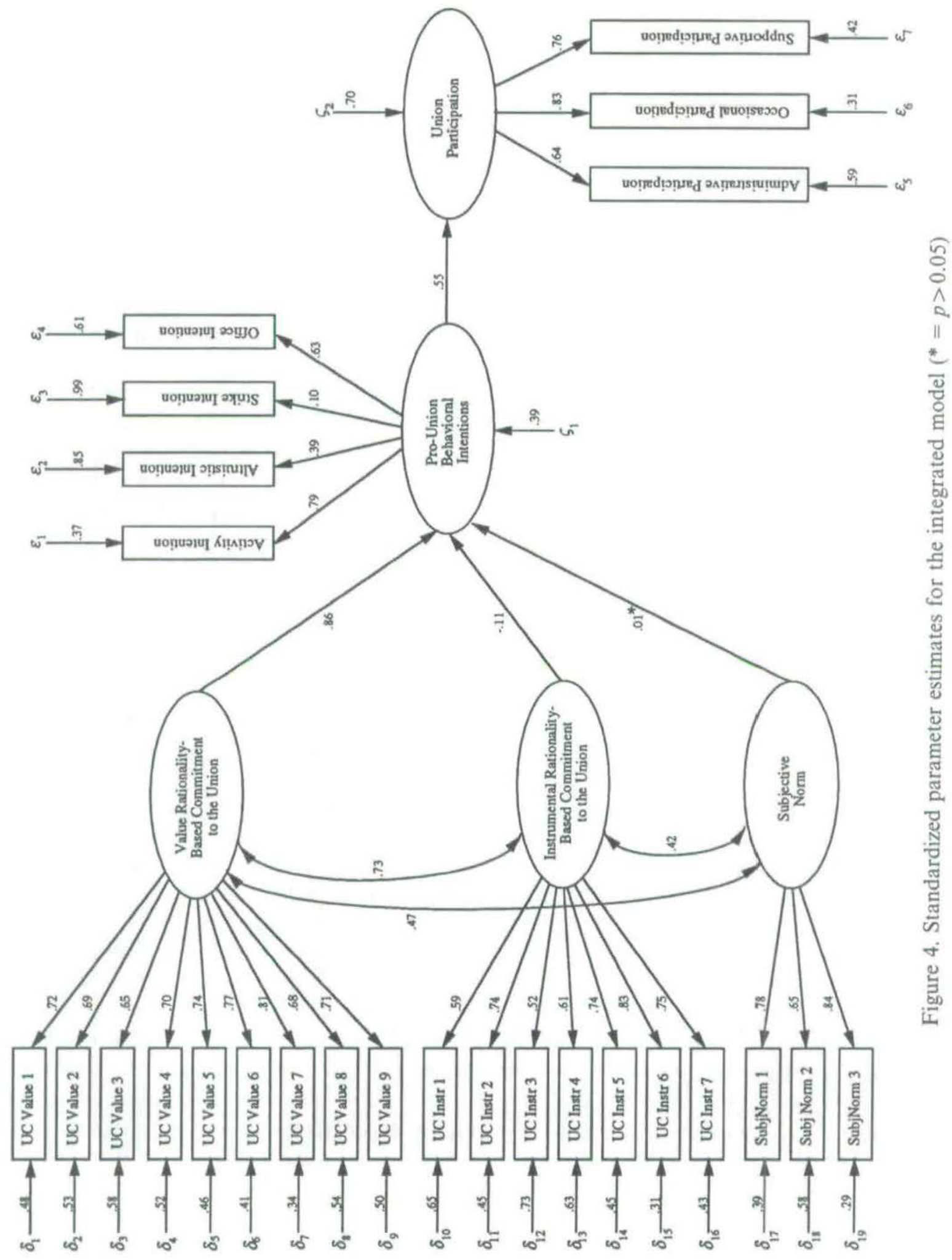


Following conventional LISREL procedures (e.g. Bentler and Bonett, 1980), we compare the fit of the hypothesized model with that of a null model (a model in which all observed variables were specified to be separate factors of their own). For estimating the goodness-of-fit of each model, we do not rely on the absolute values of the chi-square statistic, since large samples tend to produce significant chisquares, even if the fit of the model is good. Therefore, we rely on other indicators, such as the Normed Fit Index and the Parsimonious Fit Index vii. However, if one is examining whether two models differ significantly, it is possible to use a chi-square difference test (which we employ) in addition to other fit indices.

Our second analytical step is to specifically test the propositions that relate to the relative effects of union commitment dimensions and of subjective norms on behavioral intentions. To do so, we follow the procedure described by Jöreskog and Sörbom (1989). First, using the multiple regression procedure of LISREL, and regressing various pro-union behavioral intentions on instrumental commitment, value-based commitment, and subjective norms, permits us to compare the size of the coefficients. Second, we re-estimate the regression models, constraining the effects of all predictors to be equal. Since the two model types (freely estimated parameters versus equality constraints) are nested models, we rely on the chi-square difference test to see whether the propositions are supported.

\section{Results}

The path diagram in Figure 4 shows the measurement model and structural model parameter estimates of the hypothesized integrated model. The measurement model parameters provide information on the relationship between the manifest (observed) variables and the underlying latent variables (factors). The structural model parameters depict the relationships between the latent variables and also indicate the magnitudes of residuals in the endogenous variables.

The left side of Figure 4 can be seen as a factor analysis relating the observed independent variables to their latent counterparts, the exogenous variables. Clearly, the coefficients in that part of the measurement model indicate support for our first proposition, i.e. that the two dimensions of union commitment are distinct constructs. Most of the individual items load well onto their respective latent value-rational and instrumental-rational dimensions. All parameters linking the exogenous and endogenous variables to manifest variables are significant $(p<0.05)^{\text {viii. }}$ 
Table 3. Fit indices for model tests

\begin{tabular}{lccccccccc}
\hline Model $(\mathrm{k})$ & $d f_{\mathrm{k}}$ & $\chi_{\mathrm{k}}^{2}$ & $d f_{\mathrm{k}-1}-d f_{\mathrm{k}}$ & $\chi_{\mathrm{k}-1}^{2}-\chi_{\mathrm{k}}^{2}$ & GFI & AGFI & RMSR & NFI & PFI \\
\hline Null model & 318 & 14082.65 & & & 0.26 & 0.19 & 0.32 & & \\
Integrated model & 292 & 1382.33 & 26 & 12700.32 & 0.91 & 0.90 & 0.05 & 0.90 & 0.89 \\
\hline
\end{tabular}

It can be seen from the structural model that the three exogenous variables are highly correlated. As expected, the value rationality-based union commitment dimension is a strong and significant predictor of pro-union behavioral intentions in the model $(Y=0.86 ; p<0.05)$, while the instrumental rationality-based commitment variable shows a weak negative relationship with activityoriented pro-union behavioral intentions $(\gamma=-0.11 ; p<0.05)$ supporting our propositions 2 and 3 .

However, contrary to our proposition 4, the parameter for the effect of subjective norms on pro-union behavioral intentions is non-significant $(\gamma=0.01 ; p>0.05)$. Although correlational data (see Table 2) show that subjective norm is positively related to specific behavioral intentions, this effect appears to 'wash out' in the structural equation ${ }^{\text {ix. }}$

Among the endogenous variables, the general pro-union behavioral intention is strongly $(\beta=0.55)$ and significantly $(p<0.05)$ predictive of the union participation variable, which was also posited in proposition 7. The residual terms for the endogenous factors indicate that the variables in the model account for 61 and 30 per cent of the variance in pro-union behavioral intentions and union participation, respectively.

Table 3 presents the fit indices for model tests. First, this table allows a comparison of the goodness-of-fit between the hypothesized model and the null model. As the table suggests, all the fit indices for the hypothesized model are high by conventional standards (GFI $=0.91, \mathrm{AGFI}=0.90, \mathrm{RMSR}=$ $0.05, \mathrm{NFI}=0.90, \mathrm{PFI}=0.89)$ and represent a substantial improvement over the fit indices for the null model. The chi-square difference test indicates that the hypothesized integrated model provides a significant improvement in fit over the null model $\left(X^{2}[26]=12700.32 ; p<0.001\right)$. Clearly therefore, these results show strong support for the integrated model used in this paper ${ }^{x}$.

Table 4 presents the multiple regression results lo assess the relative impacts of the two commitment dimensions and the subjective norm variable on various specific pro-union behavioral intentions. Some interesting results are apparent from this table.

First, the table shows that the value rational commitment dimension predicts all intentions measured, while the instrumental rational dimension predicts only one intention, i.e. the intention to remain a member. This result is consistent with propositions 2 and 3 . Contrary to our postulation in 
proposition 4, however, subjective norm is predictive only of one specific intention (membership intention).

Table 4. Results of multiple regressions predicting specific pro-union behavioral intentions

\begin{tabular}{|c|c|c|c|c|c|}
\hline \multirow[t]{2}{*}{ Predictor } & \multicolumn{5}{|c|}{ Standardized regression coefficients } \\
\hline & $\begin{array}{l}\text { Membership } \\
\text { intention }\end{array}$ & $\begin{array}{c}\text { Activity } \\
\text { intention }\end{array}$ & $\begin{array}{c}\text { Office } \\
\text { intention }\end{array}$ & $\begin{array}{l}\text { Altruistic } \\
\text { intention }\end{array}$ & $\begin{array}{c}\text { Strike } \\
\text { intention }\end{array}$ \\
\hline Value rationality-based commitment & $0.45^{*}$ & $0.65^{*}$ & $0.37^{*}$ & $0.34^{*}$ & $0.13^{*}$ \\
\hline Instrumental rationality-based commitment & $0.14^{*}$ & 0.01 & 0.04 & -0.02 & 0.02 \\
\hline Subjective norm & $0.06^{*}$ & -0.01 & -0.00 & 0.02 & -0.03 \\
\hline$R^{2}$ & 0.34 & 0.43 & 0.16 & 0.11 & 0.02 \\
\hline Test for equality of regression coefficients $\left(\chi_{[2]}^{2}\right) \dagger$ & $81.02^{*}$ & $172.60^{*}$ & $57.72^{*}$ & $44.21^{*}$ & $8.86^{*}$ \\
\hline
\end{tabular}

Although examining the path model in Figure 2 would allow us to conclude that the attitude variables are stronger predictors of general behavioral intentions than subjective norm (the path coefficient for subjective norm is much lower and non-significant), a more complete test of this proposition is accomplished by evaluating the results of the multiple regressions. The beta weights, in representing the relative importance of each variable in the equation, clearly show that attitudes (I.e. commitment dimensions) are better predictors of intentions than are subjective norms (proposition 5) and. more specifically, that value rationality-based commitment is the strongest predictor of all intentions (proposition 6). In addition, in the bottom line of Table 4, in which models based on freely estimated regression parameters are compared with corresponding models in which equality constraints are imposed, the chi-square difference tests also suggest that the relative impacts of the two attitudinal variables and the subjective norms variable on various specific intentions are significantly different. In general therefore, the results reported here signify strong support for the integrated theory developed in this paper.

Further support for the validity of the integrated model is provided by a consideration of concurrent and discriminant validity. Here, concurrent validity concerns whether the central concepts, i.e. the commitment dimensions, actually predict other constructs that the theory indicates that they should predict; discriminant validity refers to differences between the two dimensions in terms of divergent relationships to other variables. Consistent with the integrated theory, the results suggest that the two union commitment dimensions correlate with each other, but are distinct, and demonstrate both discriminant and concurrent validity. For example, as postulated, both kinds of commitment 
predict the intention to retain membership; further, value-rationally committed members are more likely than instrumentally committed members to participate in union activity.

\section{Discussion and conclusions}

The purpose of this paper was to develop a new conceptualization of union commitment that would provide a theoretical solution to the dimensionality debate. The theory of union commitment outlined in this paper represents an integration of two different approaches that allow us to specify a precise nomological network with a clear definition of the constructs and the relationship between different constructs. The empirical investigations appear to strongly support the theory postulated.

In specific terms, the results of the linear structural equation models provide strong support for the two dimensions of union commitment articulated by the integrated theory, i.e. instrumental and value rationality-based commitment to the union. In terms of convergent validity (Campbell and Fiske, 1959), the model parameters indicate that the correlations among the items used to assess the commitment dimensions result from two different underlying latent variables.

The integrated theory also constitutes a framework for studying both the process of union commitment and its outcomes, the behavioral intentions and union participation variables. In specifying the relationship between components of the commitment model, the causal connections posited by the theory provide a dynamic framework that has hitherto been absent in union commitment research. The integrated theory provides a more stable basis for comparisons of union commitment across different national and international settings, and is flexible enough to allow researchers to study both general behavioral intentions, on the one hand, and specific intentions on the other. For example, the theory could be used in the specific instance of studying union members" willingness to strike, but also to study the members' general willingness to do work on behalf of the union.

The integrated theory's implication for unions is that members who are more ideologically committed to their union can be counted on to really work for the union, while members whose commitment is drawn from instrumental reasons are less likely to be willing to work on behalf of the union. For unions wishing to increase member activism (an important need given the general decline of unionism in several Western nations; Kuruvilla and Fiorito, 1994), the challenge for unions is to develop an ideological bond with their members (cf. Goldthorpe et al., 1968; Gordon and Ladd. 1993; Offe and 
Wiesenthal. 1980; Spinrad, 1960) and to find ways of turning instrumentally committed members to value-rationally committed members.

Although the specific methods by which this can be achieved is left for union policy makers to decide, the theory provides some guide, in terms of the antecedents. Apart from the consequences of union commitment, the integrated theory also suggests several variables relating to the antecedents of union commitment, notably the informational basis for attitude formation articulated by the Fishbein and Ajzen (1975) theory. For example, activities influencing members' belief systems, such as supplying members with regular information, organizing formal socialization programs, and providing opportunities for informal contacts with other members during the first days of membership, are all antecedents of union commitment arising out of the integrated theory.

The theory has potential application also in studies that investigate union joining. Clearly, members join unions for instrumental reasons as well as non-instrumental reasons (Klandermans, 1986; Wheeler and McClendon. 1991), although the strength of these reasons may vary across individuals as well as across cultures. In particular, the theory is also versatile in that it can be used in union environments characterized by both business and welfare unionism. In the U.S., for instance, the AFL-CIO has recently instituted a program of associate memberships whereby associate members have access to numerous benefits such as cheaper health insurance and union credit cards. Members joining associate member programs are likely to be motivated to join for instrumental reasons. Although this will increase membership strength, it may not be the right strategy if the union wants a more activist membership, given that value-rationally committed individuals are more likely to be active members. On the other hand, it is also plausible that American society is so vastly different from Swedish society that the qualifications of instrumental rationality-based commitment may be different in the U.S. and may, in fact, promote member activism to some extent. Although we are arguing for a universalistic theory, since attitudinal constructs should be similar across countries, we acknowledge the possibility that the relative impact of instrumental- and value-rational dimensions may be different across societal boundaries. Future research may wish to address this issue.

Finally, a few limitations of this study merit discussion. First, although the regression results indicate that subjective norm is a significant determinant of the intention to retain membership, contrary to our proposition, however, subjective norm did not predict either specific activity oriented behavioral intentions in the regression analyses or the general intention in the structural equation model. This finding is inconsistent with the Fishbein and Ajzen (1975) framework and previous research (Kelloway and Barling, 1993) in which subjective norm has been identified as a significant predictor of a 
general willingness to work for the union. A plausible partial explanation is that the required levels of specificity were absent in our measures.

Second, one significant limitation of this study is the cross-sectional nature of our data. Longitudinal data are more appropriate for the testing of causal relationships (Baltes and Nesselroade, 1979; Bentler, 1980), and can also help in establishing the inter-temporal stability of union commitment dimensions.

In general, however, the integrated theory and the results presented here indicate a solution to the dimensionality debate in union commitment research. Clearly, replication efforts in different samples drawn from other types of union members (such as white-collar workers and professional workers), different national contexts, and different industrial relations systems will be useful in establishing both the construct validity and the cross-cultural generalizability of the integrated theory. Future research may wish to consider these aspects.

Further empirical examinations of the integrated theory could preferably also involve other types of organizations. We believe that the two dimensions of instrumental rationality and value rationality have potential application to the study of attitudes towards other forms of organizations, such as companies, social movements, cooperatives and other voluntary organizations as well.

\section{References}

Abrahamsson, B. (1993a). The Logic of Organizations., Sage, Newbury Park. CA.

Abrahamsson, B. (1993b). IVhy Organizations? How and Why People Organize, Sage, Newbury Park, CA.

Abrahamsson, B. (1993c). 'Union structural change". Economic and Industrial Democracy, 14. 399-421.

Ajzen, I. and Fishbein. M. (1980). Understanding Attitudes and Predicting Social Behavior, Prentice-Hall, Englewood Cliffs.

Allen N. J. and Meyer, J. P, (1990), The measurement and antecedents of affective, continuance and normative commitment to the organization'. Journal of Occupational Psychology, 63. 1-18.

Allport. G. W. (1935). 'Attitudes', In: Murchison, C. (Ed.) A Handbook of Social Psychology, Clark University Press, Worcester. MA, pp. 798-844.

Bain, G. S. and Elsheikh, F. (1976). Union Growth and the Business Cycle: An Econometric Analysis, Basil Blackwell, Oxford.

Baltes, P. B. and Nesselroade, J. R. (1979). 'History and rationale of longitudinal research". In: Nesselroade, J, R. and Baltes, P. B. (Eds) Longitudinal Research in the Study of Behavior and Development, Academic Press, New York, pp. 1-39.

Becker. H. S. (1960). 'Notes on the concept of commitment'. Journal of Sociology, 66. 32-42. 
Bem. D. J. (1965). 'An experimental analysis of self persuasion'. Journal of Experimental Social Psychology, 1, 199218.

Bem, D. J. (1972). 'Self-perception theory'. In: Berkowitz, L. (Ed.) Advances in Experimental Social Psychology, Academic Press. New York, pp. 1-62.

Bentler, P. M. (1980). "Multivariate analyses with latent variables: Causal modeling'. Annual Review of Psychology. $31.419^{\wedge} 56$,

Bentler. P. M. and Boneti, D. G. (1980). 'Significance tests and goodness-of-fit in the analysis of covariance structures'. Psychological Bulletin, 88, 588-606.

Bentler. P. M. and Speckart, G, (1979). 'Models of attitude-behavior relations', Psychological Review, 86, 452-464.

Bentler, P, M, and Speckart, G, (1981). 'Attitudes "cause" behaviors: A structural equation analysis'. Journal of Personality and Social Psychohgy. 40. 226-238,

Bollen, K. A. (1989). Structural Equations with Latent Variables, Wiley, New York,

Breckler, S. J. (1990). 'Applications of covariance structure modeling in psychology: Cause for concern?' Psychological Bulletin, 107, 260-273.

Campbell. D. T. and Fiske, D. W, (1959). 'Convergent and discriminant validation by the multitrait-multimethod matrix". Psychological Bulletin, 56. 81-105.

Child, J., Loveridge, R. and Warner, M. (1973). 'Towards an organizational study of trade unions'. Sociology, 7, 71-91.

Cronbach, L, J. and Meehl. P. E. (1955). 'Construct validity in psychological tests'. Psychological Bulletin, 52. 281-302.

Dubin, R., Champoux, J. E. and Porter, L. W. (1975). 'Central life interests and organizational commitment of bluecollar and clerical workers'. .Administrative Science Quarterly, 20, 411-421.

Eaton, A. E., Gordon, M, H. and Keefe. J. H. (1992). 'The impact of quality of work life programs and grievance system effectiveness on union commitment'. Industrial and Labor Relations Review, 45,

591-604.

Enz, C. A. (1988). 'The role of value congruity in intraorganizational power'. Administrative Science Quarterly, 33, 284-304.

Etzioni, A, (1975). A Comparative Analysis of Complex Organizations, Free Press, New York.

Fiorito, J. (1992). 'Unionism and altruism'. Labor Studies Journal, 17, 19-34.

Fishbein, M. and Ajzen, I. (1975). Belief Attitude. Intention and Behavior: An Introduction to Theory and Research. Addison Wesley. Reading, MA,

Freeman, R, B. and Medoff. J- L. (1984). What Do Unions Do"\} Basic Books, New York.

Friedman, L. and Harvey, R. J. (1986). "Factors of union commitment: The case for a lower dimensionality'. Journal of Applied Psychology, 71, 371-376. 
Fullagar. C. (1986). "A factor analytic study on the validity of a union commitment scale'. Journal of Applied Psychology, 71. 129-136.

Fullagar, C. and Barling, J. (1989). 'A longitudinal test of the antecedents and consequences of union loyalty'. Journal of Applied Psychology, 74, 213-227.

Fullagar, C. McCoy. D. and Schull, C. (1992). The socialization of union loyalty'. Journal of Organizational Behavior. $13,13-27$.

Gallagher. D, G., McLean-Parks. J, and Wetzel, K. W. (1987), 'Methodological considerations in the measurement of union participation: The issue of a multidimensional construct". Paper presented at the 19th Annual Meeting of the Decision Sciences Institute, Boston, MA, November 1987.

Gallagher. D. G, and Strauss, G. (1991). 'Union membership attitudes and participation'. In: Strauss. G., Gallagher, D, G, and Fiorito, J. (Eds) The State of the Unions, Industrial Relations Research Association, Madison, WI, pp. 139-174.

Goldthorpe. J. H., Lockwood. D., Bechofer, F. and Platt, J, (1968). The Affluent Worker: Industrial Attitudes and Behavior. Cambridge University Press, Cambridge.

Gordon, M. E, and Ladd, R. T. (1993), 'Union commitment: An update'. Paper presented at the Comparative Research on Union Commitment workshop, Amsterdam, June 21-23, 1993.

Gordon, M. E., Philbot. J. W., Burt, R., Thompson, C. A. and Spiller, W. E. (1980). • Commitment to the union: Development of a measure and an examination of its correlates', Journal of Applied Psychology, 65, 479^99.

Hom, P. W., Katerberg, R. J. and Hulin, C. L. (1979). "Comparative examination of three approaches to the prediction of turnover". Journal of Applied Psychology, 64, 280-290.

Hrebiniak, L. G. and Alutto, J. A. (1972). "Personal and role-related factors in the development of organizational commitment', Administrative Science Quarterly, 17, 555-573.

Iverson, R. D. and Kuruvilla, S. (1990). "Does dual commitment underlie the constructs of company and union commitment?' In: Proceedings of the 43rd Annual Meeting, Industrial Relations Research Association, Madison. WI, pp. 208-217.

Iverson, R. D. and Kuruvilla, S. (1991). 'Does dual commitment underlie company and union commitment? An application of second-order confirmatory factor analysis". Paper presented at the Annual Meeting of the Academy of Management. Miami. 1991.

Iverson, R. D. and Kuruvilla, S. (1993). "Antecedents of union commitment: The influence of organizational and job context in a study of school teachers'. Paper presented at the Comparative Research on Union Commitment workshop, Amsterdam, June 21 -23. 1993.

James, L. R., Mulaik, S. A., and Brett, J. M. (1982). Causal Analysis, Sage, Beverly Hills, CA. 
Janson, C.-G. (1990). 'Retrospective data, undesirable behavior, and the longitudinal perspective'. In: Magnusson, D. and Bergman, L. R. (Eds) Data Quality in Longitudinal Research. Cambridge University Press, Cambridge, pp. 100-121.

Johnson, W. R. (1992). 'Public and private sector comparison of an abbreviated measure of union commitment'. Journal of Collective Negotiations, 21, 15-26.

Jöreskog, K. G. and Sörbom D. (1989). LISREL 7: A Guide to the Program and Applications, 2nd edn. SPSS Inc., Chicago.

Kanter, R. M. (1968). 'Commitment and social organization: A study of commitment mechanisms in Utopian communities", American Sociological Review, 33, 499-517.

Kelloway, E. K. and Barling, J. (1993). "Members" participation in local union activities: Measurement, prediction, and replication". Journal of Applied Psychology, 78, 262-279.

Kelloway, E. K., Catano, V. M. and Southwell, R. R. (1992). "The construct validity of union commitment: Development and dimensionality of a shorter scale". Journal of Occupational and Organizational Psychology, 65, 197-211.

Kelman, H. C. (1958). 'Compliance, identification, and intemalization". Journal of Conflict Resolution, 2. 51-60.

Klandermans, B. (1986). "Psychology and trade union participation: Joining, acting, quitting'. Journal of Occupational Psychology, 59, 198-204.

Klandermans, B. (1989). "Union commitment: Replications and tests in the Dutch context". Journal of Applied Psychology, 74, 869-875.

Kuruvilla, S. (1989). 'Union attitudes: Three essays on dimensionality, discriminant validity and union attitude formation'. Unpublished Ph.D. Thesis, University of Iowa.

Kuruvilla, S. and Fiorito, J. (1994). 'Who will help? Willingness to work for the union'. Relations Industrielles, 49, 548-574.

Kuruvilla, S., Galagher, D. G., Fiorito, J. and Wakabayashi, M. (1990). 'Union participation in Japan: Do Western theories apply?' Industrial and Labor Relations Review. 43, 374-389.

Kuruvilla, S., Gallagher, D. G. and Wetzel, K. (1993). "The development of members" attitudes towards their unions: Sweden and Canada". Industrial and Labor Relations Review, 46, 499-515.

Kuruvilla, S. and Sverke, M. (1993). 'Two dimensions of union commitment based on the theory of reasoned action: Cross-cultural comparisons', Research and Practice in Human Resource Management., 1, 1-16.

Ladd, R. T., Gordon, M. E., Beauvais, L. L. and Morgan, R. L. (1982). 'Union commitment: Replication and extension". Journal of Applied Psychology, 67. 640-644.

McShane. S. L. (1986). 'The multidimensionality of union participation". Journal of Occupational Psychology, 59. 177-187.

Mellor, S. (1990). 'The relationship between membership decline and union commitment: A field study of local unions in crisis". Journal of Applied Psychology, 75, 258-267. 
Montgomery, B. R. (1989). 'The influence of attitudes and normative pressures on voting decisions in a union certification election". Industrial and Labor Relations Review, 42, 262-279.

Mowday, R. T., Steers, R. M. and Porter, L. W. (1979). "The measurement of organizational commitment'.

Newton. L. A. and Shore, L, M. (1992). "A model of union membership; Instrumentality, commitment, and opposition". Academy of Management Review, 17, 275-298.

$\mathrm{Ng}$, I. (1989). 'Determinants of union commitment among university faculty', Relations Industrielles 44, $769-783$.

Nicholson, N., Ursell, G. and Lubbock, J. (1981). 'Membership participation in a white-collar union'. Industrial Relations, 20, 162-177.

Offe, C. and Wiesenthal, H, (1980). Two logics of collective action: Theoretical notes on social class and organizational form'. In: Zeitlin, M. (Ed.) Political Power and Social Theory, JAI Press, Greenwich, CT, pp. 67-115.

Olson, M. (1971). The Logic of Collective Action. Public Goods and the Theory of Groups, Harvard University Press. Cambridge. MA.

O'Reilly, C. and Chatman, J. (1986). 'Organizational commitment and psychological attachment: The effects of compliance, identification, and internalization on prosocial behavior'. Journal of Applied Psychology. 71,492-499.

Poole, M. (1981). Theories of Trade Unionism: A Sociology of Industrial Relations, Routledge and Kegan Paul. London.

Porter, L. W., Crampon, W. J. and Smith. F. J. (1976). "Organizational commitment and managerial turnover: A longitudinal study', Organizational Behavior and Human Performance, 15, 87-98.

Roberts, K. H., Hulin, C. L. and Rousseau. D. M. (1978). Developing an Interdisciplinary Science of Organizations. Jossey-Bass. San Francisco.

Savery, L., Soutar, G. N. and Dufty, N. (1990). "Union commitment: The case of the ABEU'. Discussion paper 3/90, Western Australian Labour Market Research Centre.

Schein. E. H. (1985). Organizational Culture and Leadership, Jossey-Bass, San Francisco.

Selznick, P. (1957). Leadership in Administration: A Sociological Interpretation, Row-Peterson, Evanston, IL.

Sen. A. (1982). "Rational fools? A critique of the behavioural foundations of economic theory'. In: Sen, A. (Ed.) Choice. Welfare and Measurement. Blackwell, Oxford, U.K., pp. 84-106.

Sherer, P. D. and Morishima. M. (1989). 'Roads and roadblocks to dual commitment: Similar and dissimilar antecedents of union and company commitment', Journal of Labor Research. 10, 311-330.

Spinrad. W. (1960). 'Correlates of trade union participation: A summary of the literature', American Sociological Review. 25, 237-244.

Sverke, M. (1992). "Developing a measure of union commitment in Sweden: Results of a pilot study'. Paper presented at the symposium Emerging Union Structures: An International Comparison, Clark University.

Worcester. MA, March 1992. 
Sverke. M. and Abrahamsson. B. (1993), "Union commitment: A conceptualization based on instrumental and value rationality". Research report, Swedish Center for Working Life.

Sverke, M. and Kuruvilla, S. (1993). 'The union commitment dimensionality debate revisited: Towards a new conceptualization". Paper presented at the Comparative Research on Union Commitment workshop, Amsterdam, June 21-23. 1993.

Sverke. M. and Netrell. M, (1993). 'The EMUS union commitment study: Analysis of non-respondents in Main Study 1". Working Paper 9/93, Swedish Center for Working Life.

Sverke, M. and Sjöberg, A. (1994). "Dual commitment to company and union in Sweden: An examination of predictors and taxonomic split methods'. Economic and Industrial Democracy 15, 531-564.

Tetrick, L. E., Thacker, J. W. and Fields, M. W. (1989). 'Evidence for the stability of the four dimensions of the commitment lo the union scale'. Journal of Applied Psychology, 74, 819-822.

Thacker, J. W., Fields, M. W. and Barclay, L. A. (1990). 'Union commitment: An examination of antecedent and outcome factors". Journal of Occupational Psychology, 63, 215-242.

Thacker. J. W., Fields, M. W. and Tetrick, L, (1989). "Evidence of the four factors of union commitment: An application of confirmatory factor analysis", Journal of Applied Psychology., 74, 228-232.

Thacker, J. W., Tetrick. L. E., Fields, M. W. and Rempel, D. (1991) 'Commitment to the union: A comparison of United States and Canadian workers". Journal of Organizational Behavior, 12, 63-71.

Thompson. J. (1967). Organizations in Action, McGraw-Hill. New York. Thurstone, L. L. (1947). Multiple Factor Analysis. University of Chicago Press. Chicago.

Walkey, F. H. and McCormick. 1. A. (1985). 'Multiple replication of factor structure: A logical solution for a number of factors problem', Multivariate Behavioral Research, 20, 57-67.

Weber. M. (1968). Economy and Society. University of California Press, Berkeley, MA.

Wheeler, H. N. and McClendon. J, A. (1991). 'The individual decision to unionize'. In: Strauss, G., Gallagher, D. G. and Fiorito, J. (Eds) The State of the Unions, Industrial Relations Research Association, Madison, WI, pp. 47-83.

Wiener, Y. (1982). 'Commitment in organizations: A normative view'. Academy of Management Review, 7, 418428.

\section{Appendix}

While we used nine regular Likert-type items to assess value rationality-based commitment to the union, instrumental rationality-based commitment was measured by a seven-item scale derived in accordance with Ajzen and Fishbein's (1980) definition of attitude. Accordingly, each instrumental rationality-based commitment item was operationalized as the product of behavioral beliefs (perceived outcomes of membership in terms of benefits associated with being a member; five-point Likert-type scale) and corresponding outcome evaluations (a five-point scale reflecting the degree of importance associated with the realization of each outcome; Table A1, Maximum likelihood estimates of factor 
loadings on value rationality-based commitment to the union and instrumental rationality-based commitment to the union (standardized parameters; $N=1295$ ) $1=$ very unimportant, $5=$ very important). In order to equalize this scale with the other scales used, the square roots of the products were used for index construction.

We used LISREL 7 (Jöreskog and Sörbom 1989) to test the hypothesized two-factor structure of union commitment. All commitment items, with their factor loadings, are presented in Table Al. As can be seen from the table, all items have fairly strong loadings on their respective commitment factor. The inter-factor correlation is 0.73 .

The goodness-of-fit statistics, which are presented in Table A2, indicate that the proposed two dimensional solution provides a satisfactory fit to the data. Although the chi-square statistic for the twodimensional specification indicates a certain degree of lack of fit of the model to data $\left(X^{2}[103]=677.77\right.$; $\mathrm{p}<0.001)$, the other fit indicators suggest a satisfactory fit $(\mathrm{GFI}=0.94, \mathrm{AGFI}=0.92, \mathrm{NFI}=0.94, \mathrm{PFI}=0.92$, RMSR $=0.05$ ). The two-dimensional model was also compared with a null model (i.e. a model in which each item was specified as a factor of its own) and a one-factor model (i.e. a model in which all items were constrained to load on one general commitment factor). The two-factor solution provides a significant improvement in fit over the unidimensional specification $\left(X^{2}[1]=1061.01 ; p<0.001\right)$, which in turn provides a significant improvement in fit in comparison with the null model $\left(X^{2}[16]=8724,62\right.$; $\mathrm{p}<0.001)$.

\footnotetext{
' Weber (1968) also uses [two types of non-rational orientations for social action, suggesting that social action also may be affectual (i.e. determined by the emotional states and specific affects of the actor) and traditional (i.e. determined by deeply rooted habits).

ii While American unions, and lo some extent Australian and British unions, can best be described in terms of business unionism (Poole, 1981), the union movements in several European countries, including Sweden, adhere more strongly to the notion of welfare unionism (Abrahamsson. 1993c). Bain and Elsheikh (1976), for example, found that instrumental values accounted for up to 70 per cent of the change in union density in Australia, the U.K. and the U.S., while in Sweden only a small proportion of the changes in union density could be explained by instrumental motives. This suggests that the relative importance of instrumental and value rationality-based dimensions may vary across industrial relations systems.

iii We do not have clear answers to why non-respondents reported higher values on value rationality-based commitment. Perhaps this result can be explained by the difference in method of data collection qquestionnaires for respondents and telephone interviews for non-respondents). The telephone interviews may have resulted in the interviewees feeling it necessary to give socially desirable answers to our questions on value rationality-based commitment. As Janson (1990) suggests, anonymous questionnaires have the advantage that they minimize socially desirable reporting, while interviews tend to enhance it. This is likely to account for the higher means of non-respondents.

iv When the three subjective norm items were subjected to an exploratory factor analysis (ULS), one Factor was extracted (eigenvalue $=2.13$ ) - The items load strongly (the factor loadings range from 0.60 to 0.89 ) on the factor, which accounts for 71 per cent of the variance in the three items.

$\checkmark$ In the literature, union participation has been defined as a unidimensional construct (e.g. Fullagar and Barling. 1989), as a multidimensional construct (e.g. McShane. 1986; Klandermans. 1986), or, more recently, as a cumulative unidimensional construct (Kelloway and Barling. 1993). Although various specific union-oriented behaviors are in themselves meaningful, the differential requirements of participation have been largely ignored by the research (Spinrad, 1960). However, as union participation has been defined primarily through
} 
operationalization, and as we use participation primarily for validation purposes, we preferred to rely on a theoretically developed definition (McShane.

1986; Nicholson et al.. 19H1), which has also been a subject for empirical examinations (Gallagher. McLean-Parks and

Wet7el. 1987; Kuruvilla. Gallagher, Fiorito and Wakabayashi. 1990; McShane. 1986).

vi The membership intention index was excluded from the analysis since the model focused on the prediction of union participation, not of membership retention.

vii LISREL provides a chi-square lest that is generally used to assess the goodness-of-fit. The chi-square statistic is computed on the basis of the differences between the sample covariance matrix (i.e. the relations between the measured variables that are observed in the data) and a 'reproduced' covariance matrix (i.e. the relationships amongst the measured variables that are predicted on the basis of the parameters of the model). When the model fits the data well, the difference between observed and reproduced matrices is small, making the chi-square also small. The null hypothesis is that the proposed model does not differ significantly from an unconstrained model that fits the data exactly. Thus, poor fit causes large chi-square values and results in rejection of the model.

However, large chi-squares can also be obtained due to large sample sizes, as well as violations of the assumptions of multivariate normality, and hence, using the chi-square statistic alone is problematic (cf. Bentler, 1980; Bentler and Bonett, 1980; Breckter. 1990). Due to this limitation of the chi-square, the evaluation of the goodness-of-fit of the model is based on considerations other than the chi-square. i.e. the goodness-of-fit index (GFI) supplied by LISREL, the AGFI, NFL PFI, and RMSR- The GFI is a measure of the relative amount of variances and covariances jointly accounted for by the model while the AGFI adjusts the GFI for the degrees of freedom in the model; these indices measure how much better the model fits to data as compared to no model at all. Unlike the chi-square, the GFI and AGFI do not depend explicitly on sample size. The NFI (normed fit index) compares the fit of the model to the null model when all items are constrained to be independent of each other (Bentler and Bonett, 1980). The PFI (parsimonious fit index; James, Mulaik and Brett, 1982) corrects the NFI by adjusting for the degrees of freedom in the model. The RMSR (root mean square residual) is the subtraction of the hypothetical covariance matrix from the sample covariance matrix (Jöreskog and Sörbom, 1989). For the GFI, AGFI, NFI, and PFI, the values range from zero to one with higher values indicating better fit. For the RMSR, the values range from zero to one with lower values indicating better fit.

viii Although some of the residuals for the $x$-variables seem relatively large, an inspection of the modification indices provided by LISREL reveals that only two constrained parameters in the matrix of loadings on exogenous variables would exceed 0.2 if these parameters were set free (in the measurement model for endogenous variables, one parameter would exceed 0.2 if set free).

ix The relationships between subjective norms and the different activity-oriented pro-union behavioral intentions dimini.sh (and even change signs) in the structural equation model, indicating a suppressor effect of value rationality based commitment.

${ }^{x}$ The integrated model was also compared with an alternative model, according to which attitudes are hypothesized to influence behavior also directly (see e.g. Bentler and Speckart, 1979, 1981). The specification of this nested model involved freeing the parameter for the effect of value rationality-based commitment on union participation. However, although the various fit indicators (GFL AGFI. RMSR. NFL and PFI) for the alternative model were similar to those of the integrated model, the chi-square difference between this model and the integrated model reveals that the alternative model did not provide a significant improvement in fit $\left.\left.i\right|^{\prime} H\right]=0.05, p>0.05$ ). These results render support for proposition 8. 